\title{
Sistem Informasi Kepegawaian UPT Kesatuan Pengelolaan Hutan Produksi Kapuas Tengah UNIT XI
}

\author{
Nova Noor Kamala Sari ${ }^{1}$, Putu Bagus Adidyana Anugrah Putra ${ }^{2}$, Widiatry ${ }^{3}$ \\ 1,2,3 Universitas Palangka Raya \\ e-mail: ${ }^{1}$ novanoorks@it.upr.ac.id, ${ }^{2}$ putubagus@it.upr.ac.id, ${ }^{3}$ widiatry@it.upr.ac.id
}

\begin{abstract}
Abstrak
Pada Unit Pelayanan Teknis Kesatuan Pengelolaan Hutan Produksi (UPT-KPHP) Kapuas Tengah Unit XI Kapuas Tengah Unit XI dalam melaksanakan tugasnya masih belum menerapkan sistem informasi untuk memfasilitasi pengolahan data pegawai, pengolahan Daftar Urut Kepangkatan, pengolahan Sasaran Kerja Pegawai (SKP), pengolahan Penilaian Kerja Pegawai (PKP), serta Kenaikan Pangkat untuk jabatan struktural. Hal tersebut menimbulkan beberapa masalah bagi UPT-KPHP Kapuas Tengah Unit XI seperti penyimpanan informasi dalam bentuk cetakkan pada kertas, pencarian suatu berkas yang disimpan pada rak-rak berkas, kerusakan atau kehilangan arsip, dan sarana penyimpanan arsip. Sehingga, penyelesaian dari masalah ini adalah dibangunnya sebuah sistem informasi kepegawaian berbasis website bagi UPT-KPHP Kapuas Tengah Unit XI. Sistem Informasi Kepegawaian dirancang dan dibangun metodologi waterfall menurut lan Sommerville. Adapun tahapannya yaitu Requirements Definition, System dan Software Design, Implementation and Unit Testing, Integration and System Testing, Operation and Maintenance. Pada tahap Requirements Definition dilakukan pembuatan flowchart. Pada tahap System dan Software Design dilakukan pembuatan Data Flow Diagram (DFD) dan Entity Relational Diagram (ERD). Metode testing yang digunakan website ini adalah metode Blackbox. Sistem informasi kepegawaian ini dapat digunakan untuk memfasilitasi pembuatan SKP dan PKP oleh pegawai dan pimpinan, mengajukan usulan pangkat untuk jabatan structural, penyusunan Data Urut Kepangkatan, dan membantu staff administrasi mengelola data kepegawaian.
\end{abstract}

Kata Kunci: Sistem Informasi Kepegawaian, SKP, PKP

\begin{abstract}
In carrying its duties, Unit of Technical Management of Unitary Forest Production in Central Kapuas Unit XI, had not yet implemented an information system to facilitate data processing of employees, process the rank of grade, organize employee performance objectives, process employee performance assessment, and manage the promotions for structural positions. It caused several problems for the unit such as storing information in the form of paper print, searching for a file in the stored file shelves, and damaging of archives or storing archives. Thus, the solution to this problem was the construction of a website-based personnel information system for Central Kapuas Unit XI. The personnel information system is designed and built a waterfall methodology by lan Sommerville. There are some stages; Requirements Definition, System and Software Design, Implementation and Unit Testing, Integration and System Testing, Operation and Maintenance. Requirements Definition stage is conducted by creating a flowchart. While in System and Software Design stage, there is creation of Data Flow Diagram (DFD) and Entity Relational Diagram (ERD). The testing method used by this website is the Blackbox method.

This personnel information system is used to facilitate the manufacture of employee performance objectives and employee performance assessment from the the employees to employer, submit the proposals for structural positions, draft the rank of grades and help administration staff to manage the data of employees.
\end{abstract}

Keywords: Personnel information System, employee performance objectives, employee performance assessment

This work is licensed under a Creative Commons Attribution-ShareAlike 4.0 International License. 


\section{Pendahuluan}

Sistem informasi adalah alat untuk menyajikan informasi sedemikian rupa sehingga bermanfaat bagi penerimanya. Tujuannya adalah untuk memberikan informasi dalam perencanaan, memulai, pengorganisasian, operasional sebuah perusahaan yang melayani sinergi organisasi dalam proses mengendalikan pengambilan keputusan.(Sari, Widiatry, \& Chitayae, 2018)

Kesatuan Pengelolaan Hutan (KPH) adalah wilayah pengelolaan hutan sesuai fungsi pokok dan peruntukannya, yang dapat dikelola secara efisien dan lestari. $\mathrm{KPH}$ terdiri dari Kesatuan Pengelolaan Hutan Konservasi (KPHK), Kesatuan Pengelolaan Hutan Lindung (KPHL) dan Kesatuan Pengelolaan Hutan Produksi (KPHP). Kesatuan Pengelolaan Hutan Produksi (KPHP) Kapuas Tengah Unit XI berlokasi di Jalan Cilik Riwut No. 11 Kabupaten Kapuas (Tim UPT KPHP Unit XI Kapuas Tengah, 2018). Pada Unit Pelaksana Teknis Kesatuan Pengelolaan Hutan Produksi (KPHP) Kapuas Tengah Unit XI terutama pada bagian Sub Bagian Tata Usaha, dalam proses pengelolaan data pegawai pihak KPHP Kapuas Tengah Unit XI masih menggunakan aplikasi Microsoft Word dan Excel, namun pengunaan aplikasi tersebut hanya sebatas untuk menghasilkan data atau arsip yang dicetak pada kertas. Hal tersebut menimbulkan beberapa masalah bagi KPHP Kapuas Tengah Unit XI seperti penyimpanan informasi dalam bentuk cetakkan pada kertas, pencarian suatu berkas yang disimpan pada rak-rak berkas, kerusakan atau kehilangan arsip, dan sarana penyimpanan arsip.

Untuk mengatasi permasalahan diatas, maka diusulkan sebuah sistem. Sistem yang akan dibuat adalah "Sistem Informasi Kepegawaian pada UPT Kesatuan Pengelolaan Hutan Produksi Kapuas Tengah Unit XI Berbasis Website". Pembuatan sistem informasi untuk UPT Kesatuan Pengelolaan Hutan Produksi Kapuas Tengah Unit XI ini diharapkan dapat meminimalisasi kekurangan yang terjadi dan dapat memfasilitasi pegawai dalam pengolahan data pegawai pada Unit Pelayanan Teknis Kesatuan Pengelolaan Hutan Produksi Kapuas Tengah Unit XI.

Dalam Sistem Informasi Kepegawaian yang dibangun dan dikembangkan ini, dapat mengolah data yang meliputi Laporan Data Urut
Kepegawaian (DUK), Sasaran Kerja Pegawai (SKP), Penilaian Kerja Pegawai (PKP), dan Kenaikan Pangkat untuk pegawai yang memiliki jabatan Struktural.

Penelitian sebelumnya mengenai sistem informasi kepegawaian yang dilakukan oleh (Fachlevi \& Syafariani, 2017) menghasilkan adanya database yang menyimpan data pegawai menjadi saling terintegrasi dan membuat sebuah fungsi yang dapat membuat sebuah persyaratan kenaikan pangkat serta pengajuan pensiun pegawai. Selanjutkan penelitian yang dilakukan oleh (Muta'aaliy, 2016) menghasilkan sistem informasi pegawai yang berdiri sendiri untuk kegiatan mengolah data maupun pencarian data pegawai serta mengefesiensikan waktu dalam mengolah data pegawai maupun pencarian data pegawai.

\section{Metode Penelitian}

Metode penelitian yang dilakukan meliputi :

1. Pengumpulan Data (Licantik \& Sari, 2019)

a. Metode Observasi

Observasi dilakukan untuk mengetahui sistem informasi pegawai pada Unit Pelaksana Teknis Kesatuan Pengelolaan Hutan Produksi (KPHP) Kapuas Tengah Unit XI

b. Wawancara (Interview)

Metode Wawancara (Interview) adalah metode yang digunakan penulis untuk mengumpulkan data dengan cara bertanya langsung kepada pihak yang membidangi kepegawaian pada Unit Pelaksana Teknis Kesatuan Pengelolaan Hutan Produksi (KPHP) Kapuas Tengah Unit XI

c. Studi kepustakaan

Metode Kepustakaan adalah metode yang digunakan penulis untuk mengumpulkan data dengan cara membaca dan mempelajari buku-buku dan literatur yang ada hubungannya dengan Sistem informasi Pegawai berbasis website (Sari, 2020)

2. Pengembangan Perangkat Lunak

Metodologi pengembangan perangkat lunak yang digunakan dalam pembuatan website ini yaitu menggunakan metodologi waterfall yang dimodifikasi. Tahapan waterfall yang dilakukan yaitu analisis, desain, implementasi dan pengujian (Sari, Putra, \& Christian, 2019)
a. Analisis sistem 
Proses pencarian kebutuhan difokuskan pada software untuk mengetahui sifat dari aplikasi yang akan dibuat, pemodelan proses bisnis menggunakan Data Flow Diagram (DFD) dan Entity Relationship Diagram (ERD)(Pressman, Roger, 2012)

b. Desain

Proses ini digunakan untuk membuat "blueprint" software seperti, perancangan basis data dan perancangan antarmuka (interface)

c. Implementasi

Proses ini akan dilakukan pembuatan perangkat lunak sesuai dengan perancangan basis data dan antar muka yang telah dilakukan pada tahap sebelumnya.(Widiatry, Sari, \& Ananingtyas, 2018)

d. Pengujian Sistem

Proses pengujian akan dilakukan dengan Blackbox Testing yang disertai dengan melakukan simulasi data (Pranatawijaya, Widiatry, Sari, \& Putra, 2019)

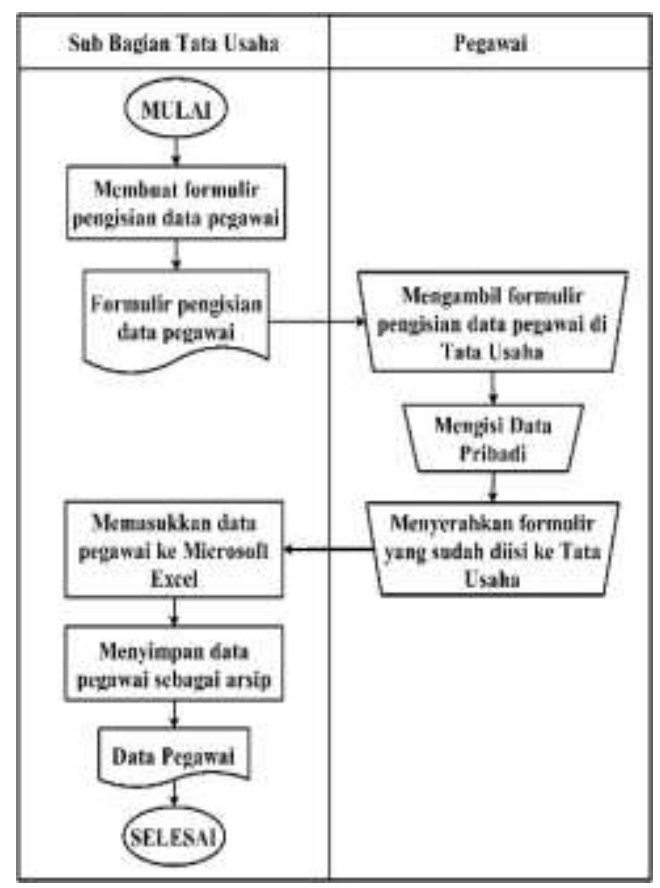

Gambar 1. Flowchart Sistem Lama Pengolahan Data Pegawai

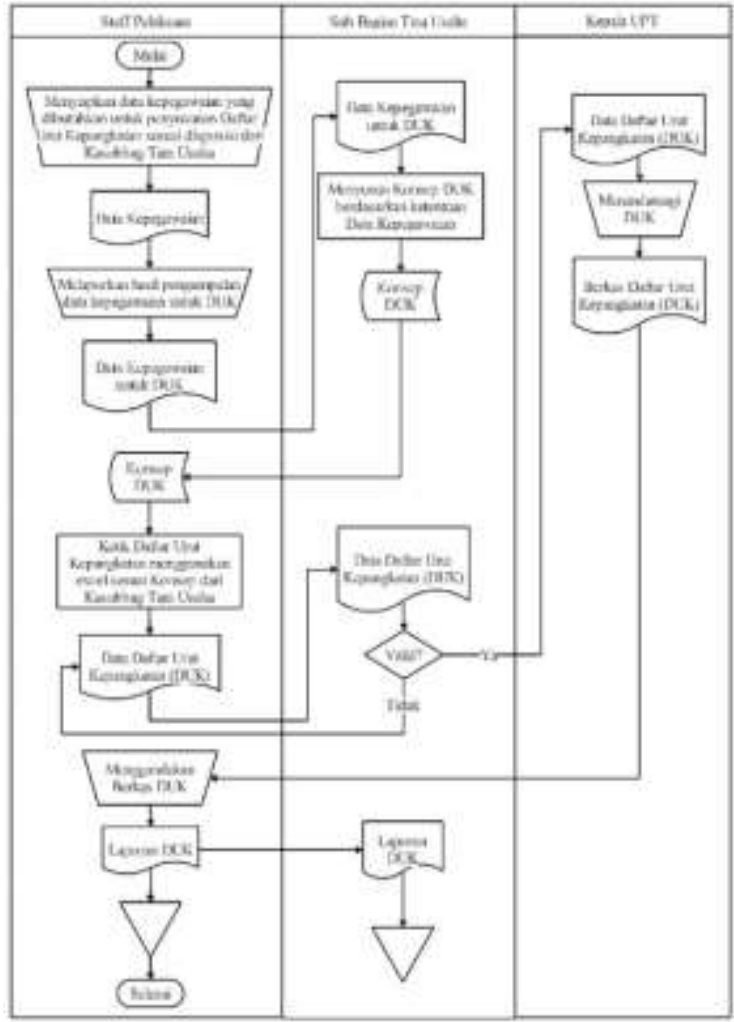

Gambar 2. Flowchart Sistem Lama Pengolahan Daftar Urut Kepangkatan

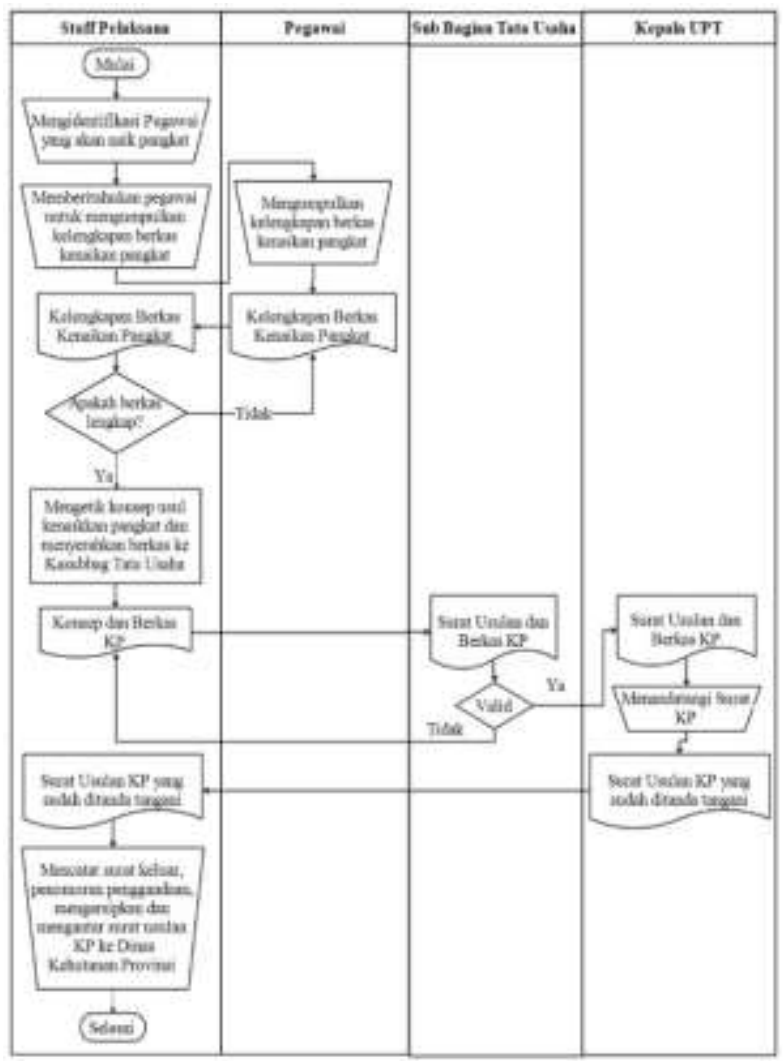

Gambar 3. Flowchart Sistem Lama Proses Kenaikan Pangkat 
JURNAL INFORMATIKA, Vol.7 No.2 September 2020

ISSN: 2355-6579 | E-ISSN: 2528-2247

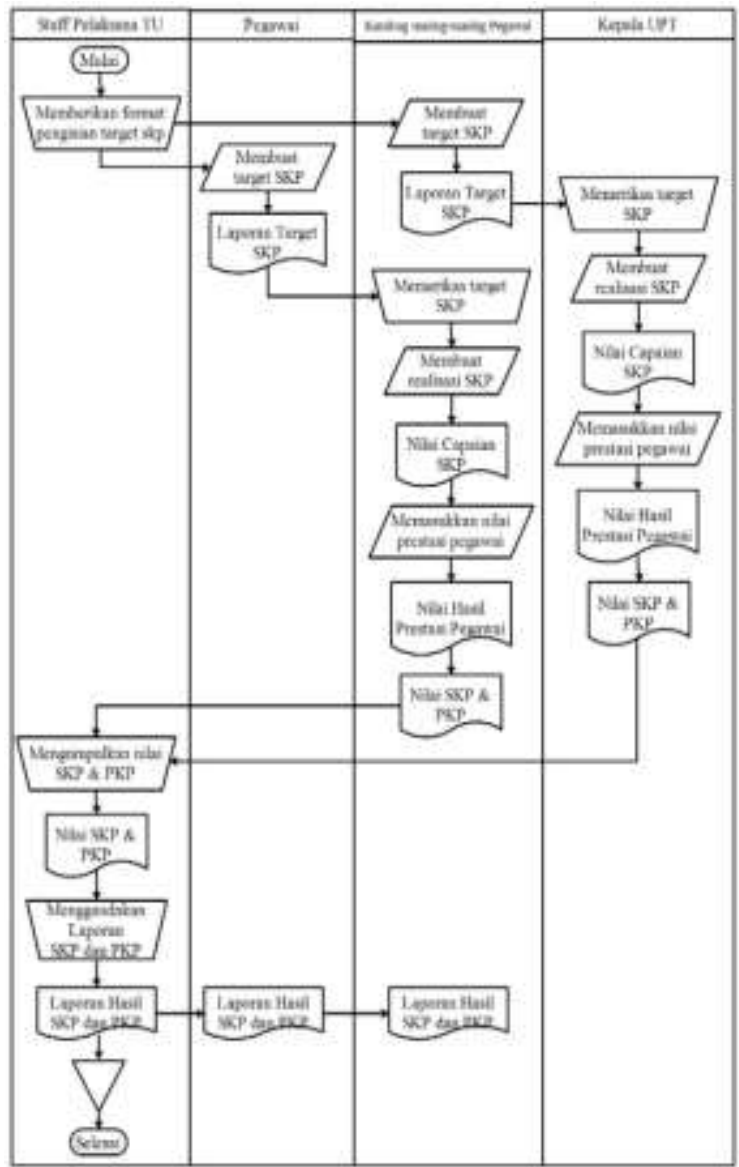

Gambar 4. Flowchart Sistem Lama SKP dan PKP



Gambar 5. Flowchart Sistem Baru

Pengolahan Data Kepegawaian

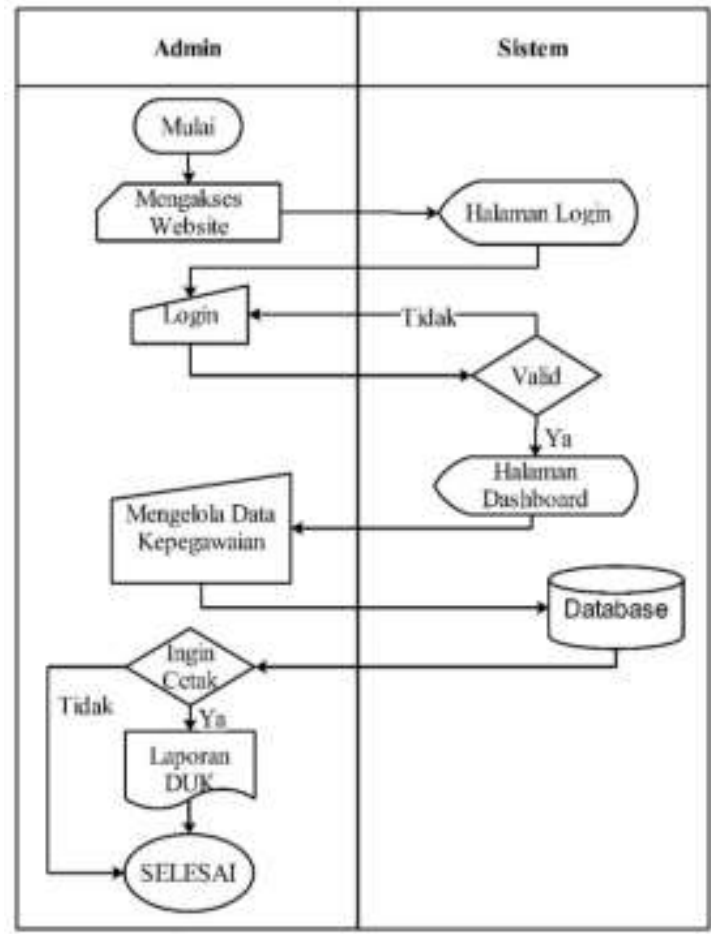

Gambar 6. Flowchart Sistem Baru Daftar Urut Kepangkatan

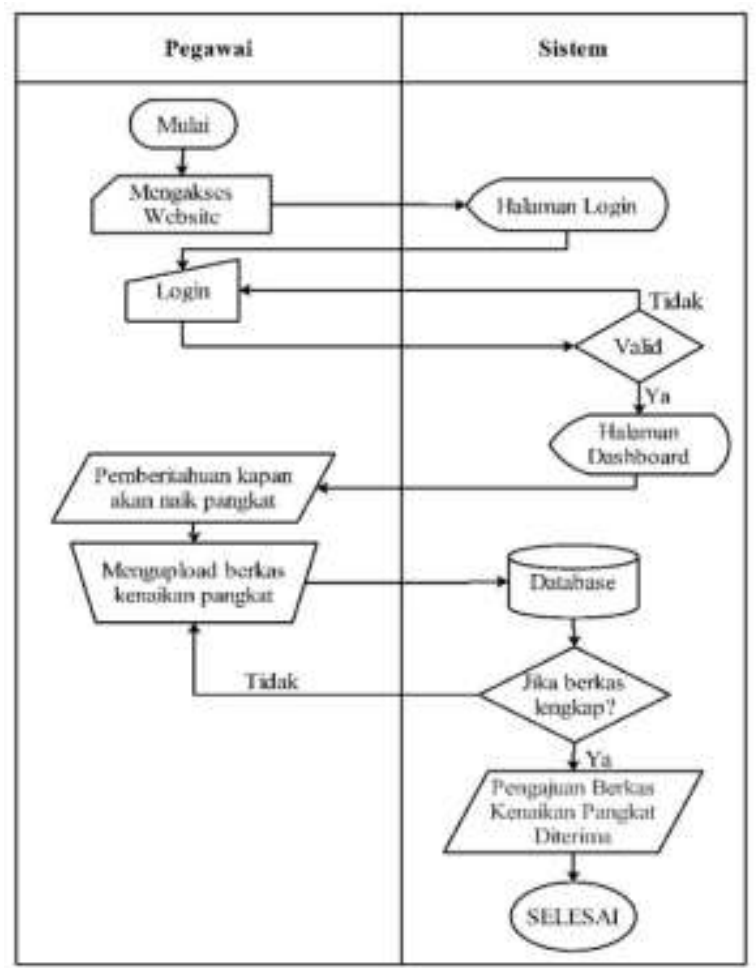

Gambar 7. Flowchart Sistem Baru Kenaikan Pangkat 


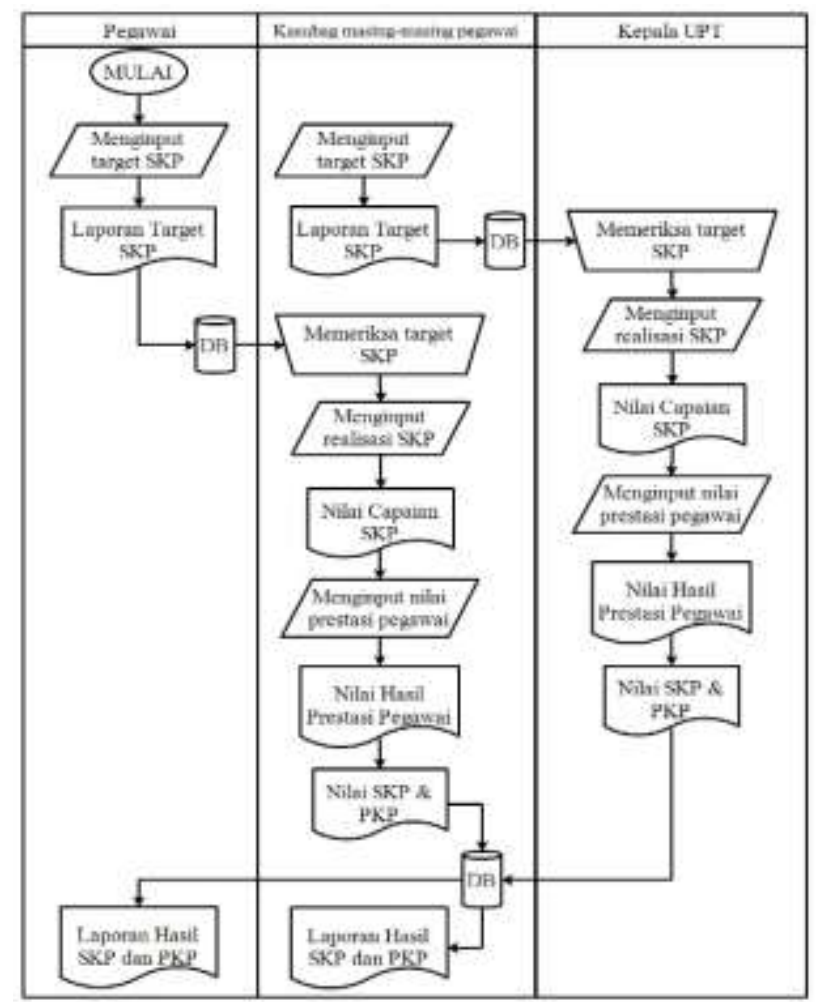

Gambar 8. Flowchart Sistem Baru SKP dan PKP

DFD (Data Flow Diagram)

DFD adalah refresentasi grafik yang menggambarkan aliran informasi dan transformasi informasi yang diaplikasikan sebagai data yang mengatur dari masukan (input) dan keluaran (output). (Sukamto \& Shalahuddin, 2014)

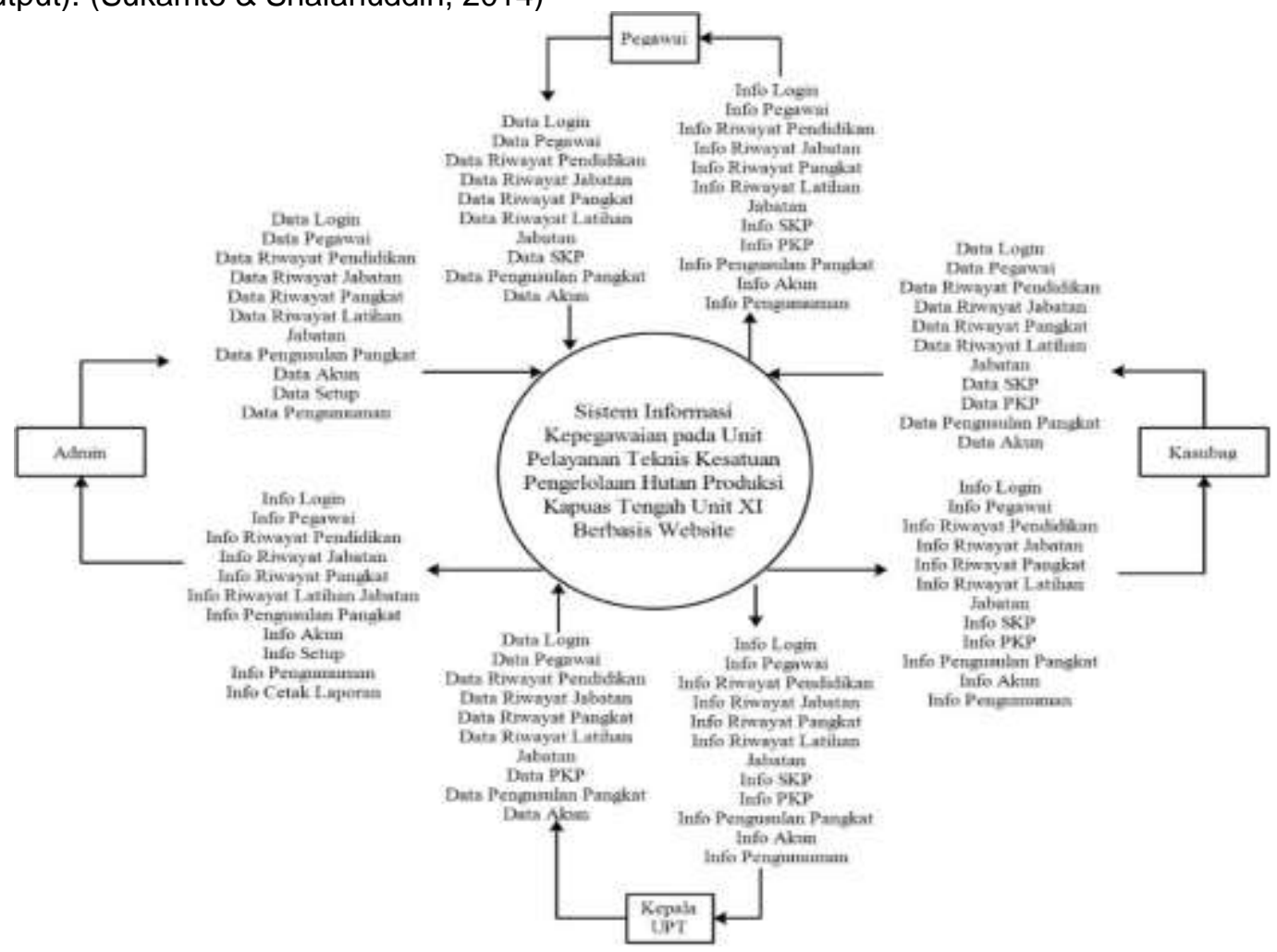

Gambar 9. Diagram Konteks sistem informasi kepegawaian UPT-KPHP Kapuas Tengah Unit $\mathrm{XI}$ 


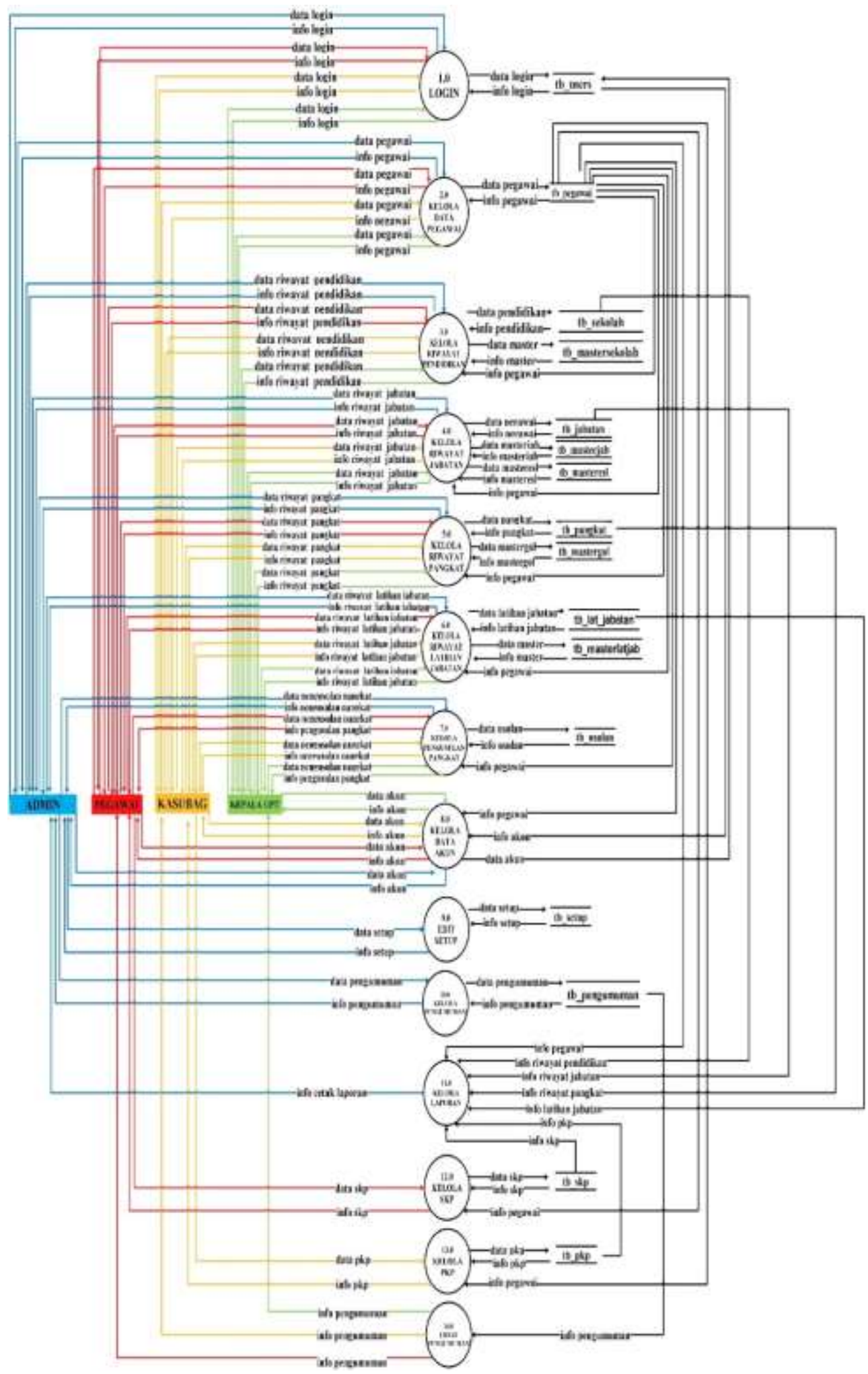

Gambar 10. Data Flow Diagram Level 1 Sistem Informasi Kepegawaian

Konsep Data Model digambarkan sebagai Entity Relationship Diagram (ERD) adalah bentuk paling awal dalam melakukan perancangan basis data relasional. (Sukamto \& Shalahuddin, 2014)

Entity Relationship Diagram (ERD) merupakan suatu model jaringan yang 
menggunakan susunan data yang disimpan dalam sistem secara abstrak(Ladjamudin, 2013)

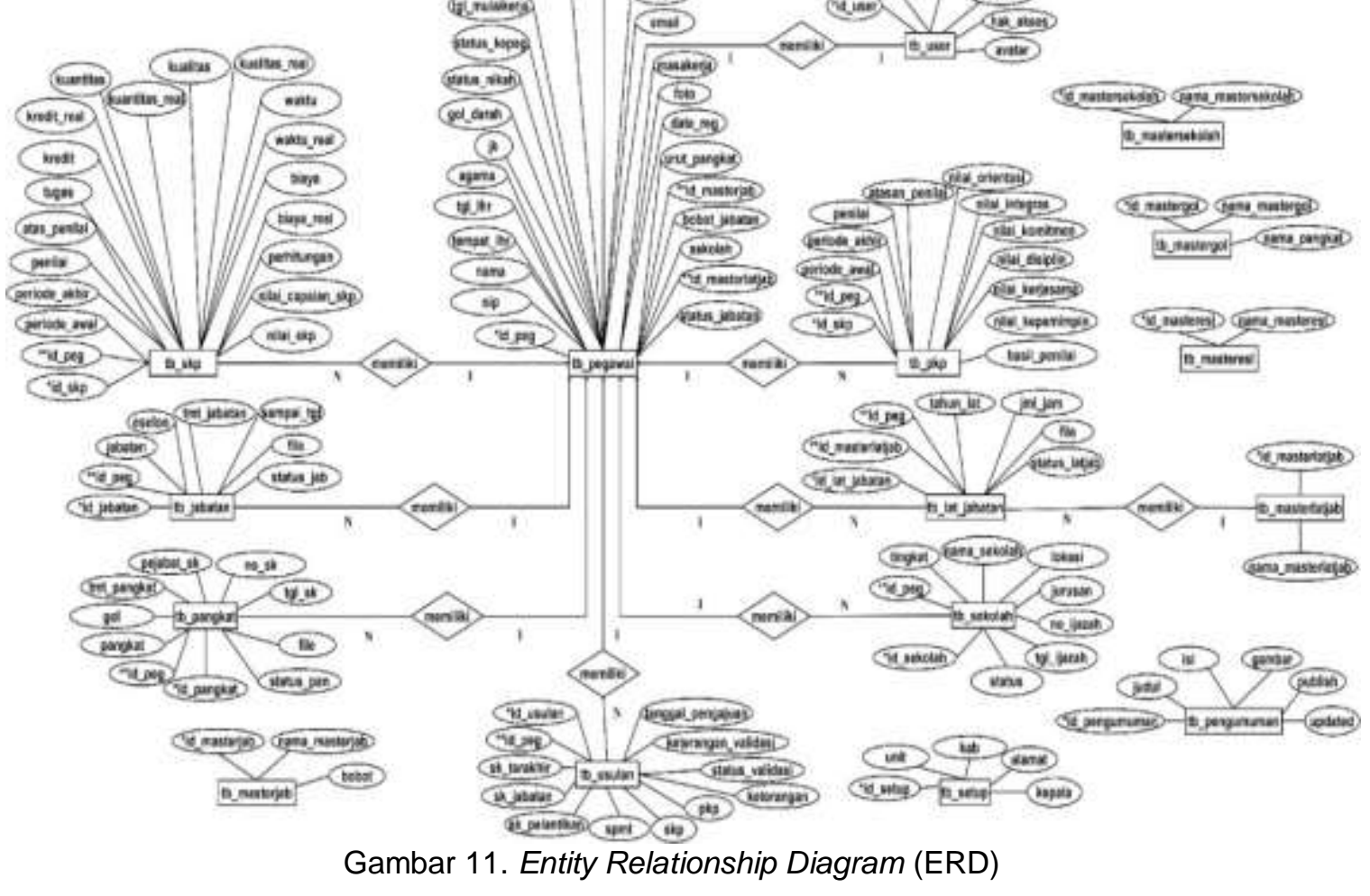

\section{Hasil dan Pembahasan}

Implementasi

a. Implementasi Halaman Admin

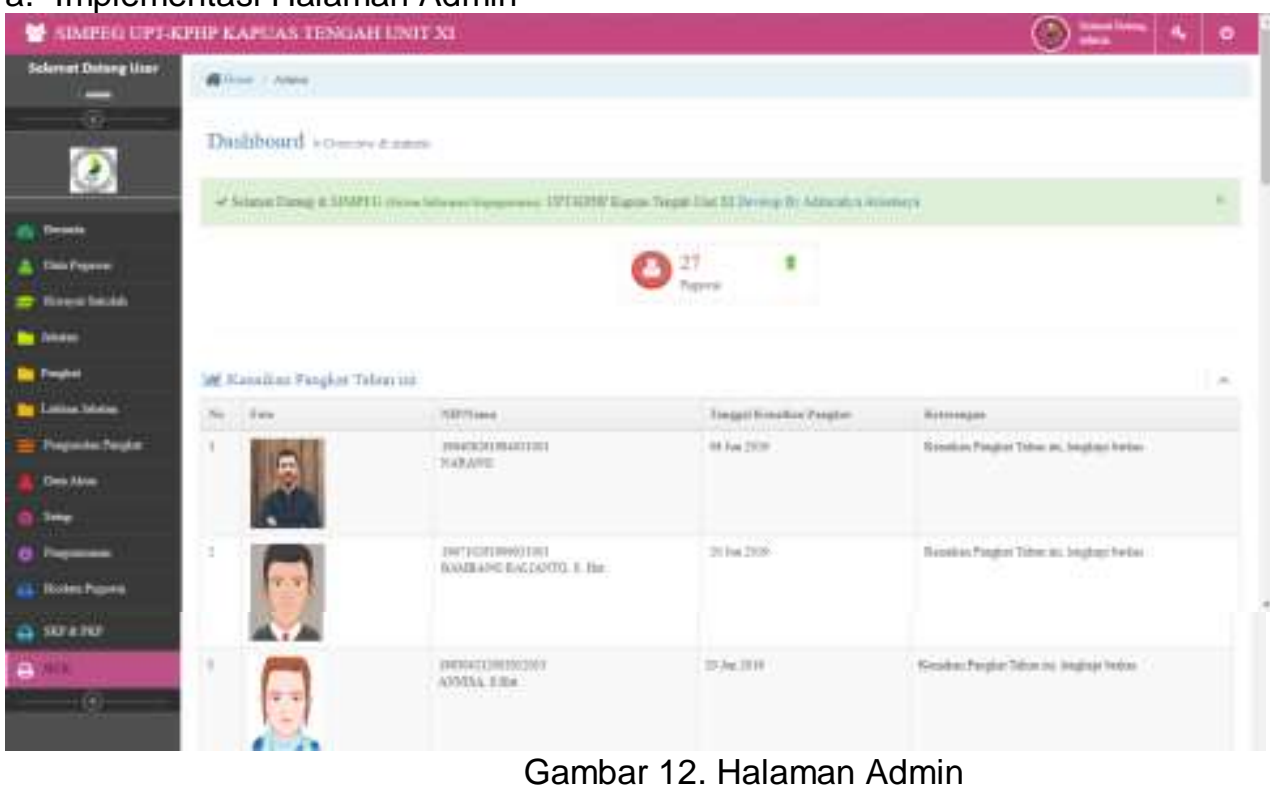


b. Implementasi Halaman Pegawai

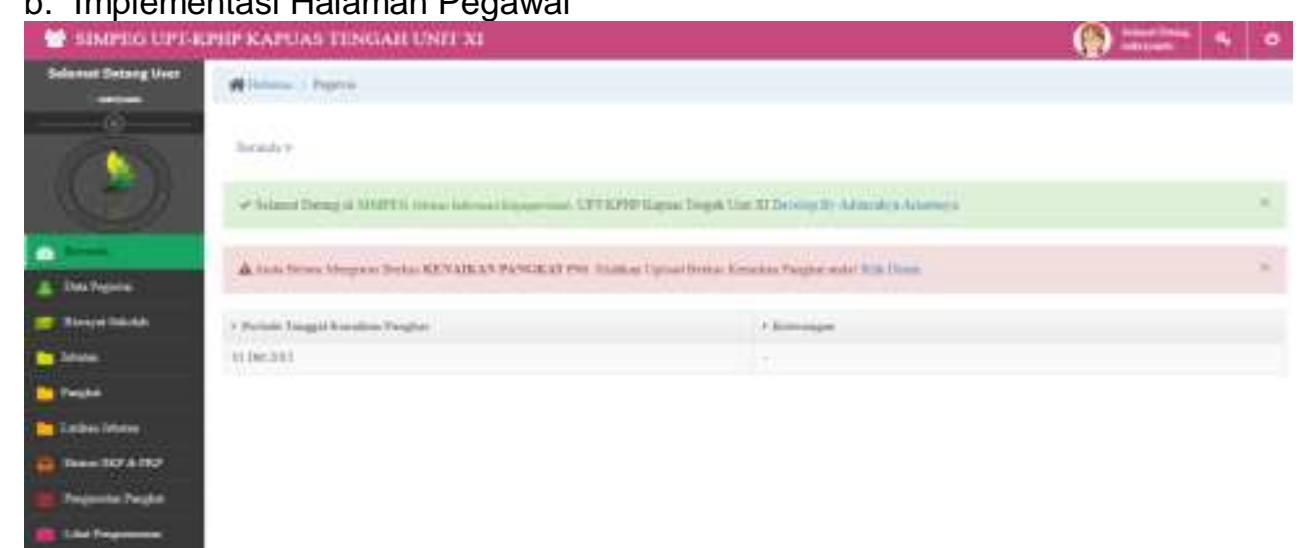

Gambar 13. Halaman Pegawai

c. Implementasi Halaman Kasubag

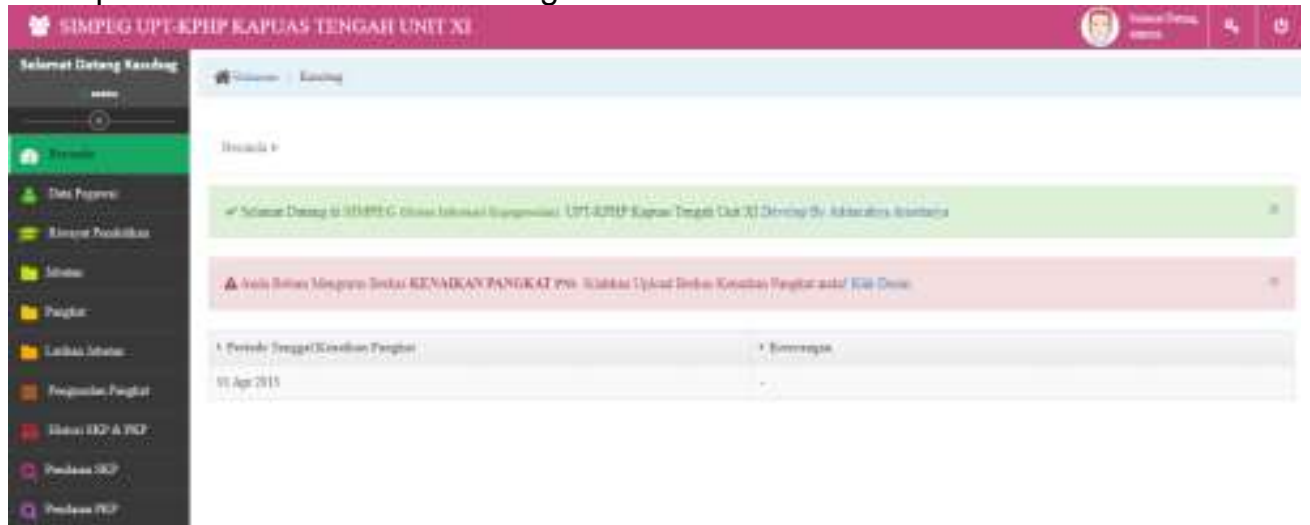

Gambar 14. Halaman Kasubag

\section{Kesimpulan}

Dalam pembuatan Sistem Informasi Kepegawaian Pada UPT Kesatuan Pengelolaan Hutan Produksi Kapuas Tengah Unit XI ini menggunakan metodologi pengembangan perangkat lunak Waterfall yang memiliki tahapan yaitu Requirements Definition (Definisi Kebutuhan), System and Software Design (Perancangan sistem dan Perangkat Lunak), Implementation and Unit Testing (Implementasi dan pengujian unit), Integration and System Testing (Integrasi dan Pengujian Sistem), dan Operation and Maintenance (Operasi dan Pemeliharaan).

Berdasarkan sistem informasi kepegawaian yang telah dirancang dan dibangun, sistem informasi ini dapat digunakan Admin untuk menyimpan data kepegawaian yang terorganisasi dengan baik, karena tersimpan di dalam database. Sistem ini juga memfasilitasi pembuatan SKP dan PKP oleh pegawai dan pimpinan, penyusunan Data Urut Kepangkatan (DUK), mengajukan usulan pangkat untuk jabatan struktural dan membantu staff administrasi mengelola data kepegawaian. Pengguna Sistem yang lain yaitu Pegawai dapat mengelola akunnya pada Sistem Informasi Kepegawaian dan mendapatkan notifikasi atau pemberitahuan bahwa beberapa bulan lagi akan naik pangkat sehingga pegawai dapat terlebih dahulu mengurus berkasberkasnya.

\section{Referensi}

Fachlevi, M. R., \& Syafariani, R. F. (2017). Perancangan Sistem Informasi Kepegawaian Berbasis Website Di Bagian Kepagawaian SDN Binakarya I Kabupaten Garut. Simetris: Jurnal Teknik Mesin, Elektro Dan IImu Komputer, 8(2), 553. https://doi.org/10.24176/simet.v8i2.14 36

Ladjamudin, A. B. Bin. (2013). Analisis dan 
Desain Sistem Informasi. Yogyakarta: Graha IImu.

Licantik, L., \& Sari, N. N. K. (2019). Pengembangan Media Informasi Ruang Kuliah Pada Fakultas Teknik Universitas Palangka Raya Berbasis Android dan Location Based Service. Jurnal Teknologi Informasi, 13(2), 3036.

Muta'aaliy, A. (2016). Perancangan Sistem informasi Kepegawaian Berbasis Web Pada PT. Parani Artamandiri Jakarta (STMIK NUSA MANDIRI). Retrieved from

https://repository.bsi.ac.id/index.php/r epo/viewitem/5063

Pranatawijaya, V. H., Widiatry, W., Sari, N. N. K., \& Putra, P. B. A. A. (2019). Sistem Informasi Geografis Mencari Rute Lokasi Travel Di Kota Palangka Raya Berbasis Website. Jurnal Teknologi Informasi, 13(1), 76-82.

Pressman, Roger, S. (2012). Rekayasa Perangkat Lunak.Pendekatan Praktisi. Edisi 7. Yogyakarta: Andi.

Sari, N. N. K. (2020). Implementasi Metode Weigthed Product Pada Sistem Pendukung Keputusan Untuk Penilaian Kinerja Karyawan Pt. Jamkrida. 14(1), 94-104.

Sari, N. N. K., Putra, P. B. A. A., \& Christian,
E. (2019). Rancang Bangun Aplikasi Mobile Learning Tenses. Jurnal Teknologi Informasi, 13(2), 37-46. https://doi.org/https://doi.org/10.36873 /jti.v13i2.253

Sari, N. N. K., Widiatry, W., \& Chitayae, N. (2018). Sistem Pendukung Keputusan untuk Seleksi Penerima Beasiswa BBP-PPA dengan Metode TOPSIS berbasis Web. Anterior Jurnal, 18(1), 86-91.

Sukamto, R. A., \& Shalahuddin, M. (2014). Rekayasa Perangkat Lunak Terstruktur dan Berorientasi Objek. Bandung: Informatika Bandung.

Tim UPT KPHP Unit XI Kapuas Tengah. (2018). Rencana Pengelolaan Hutan Jangka Panjang (RPHJP) Kesatuan Pengelolaan Hutan Produksi (KPHP) Unit Xi Pada UPT KPHP Kapuas Tengah.

Widiatry, W., Sari, N. N. K., \& Ananingtyas, A. (2018). Sistem Penunjang Keputusan Pemilihan Siswa Berprestasi Menggunakan Metode Weighted Product (Studi Kasus:Sma Muhammadiyah Kecamatan Katingan Tengah). Jurnal Teknologi Informasi, 12(2), 80-86. 